\title{
Determinants of Households' Credit Behavior in Russia
}

\author{
Submitted 12/08/19, 1st revision 20/09/19, 2nd revision 14/10/19, accepted 28/11/19
}

\section{L.I. Nivorozhkina ${ }^{1}$, S.V. Arzhenovskiy ${ }^{2}$, T.V. Toropova ${ }^{3}$, A.A. Tregubova ${ }^{4}$}

\begin{abstract}
:
Purpose: The main goal of this work is to substantiate the need to consider microeconomic statistics when analyzing consumer lending to the population, as well as implementing approaches to modeling household credit behavior at the micro level.

Design/Methodology/Approach: The article proposes and implements a comprehensive statistical approach that allows identifying the specificity of the influence of demographic, socio-economic characteristics of households on their credit activity.

Findings: The article states that loan borrowings are more often found in households with children of preschool age who are in relatively high-income groups, who much more often inform about cash incomes that do not correspond to the declared level of consumption. Members of these households are more likely to work. The age range of borrowers expanded during the study period, and no prevalence of any age group was observed.

Practical Implications: This result is of great practical importance, since, as already indicated, in assessing the solvency of the borrower, credit organizations are mainly focused on individual characteristics.

Originality/value: It was found that the hypothesis that individual characteristics are important determinants of household lending activity has not been confirmed. And variables that characterize households significantly affect their credit behavior.
\end{abstract}

Keywords: Credit behavior, households, determinants of credit activity, Logit model.

JEL code: D14, G02.

Paper type: Research article: Households' Credit.

Acknowledgements:

The reported study was funded by RFBR according to the research project \# 19-010-00009.

\footnotetext{
${ }^{l}$ Professor, Head of the Department, Department of Statistics, Econometrics and Risk Assessment, Rostov State University of Economics, Rostov-on-Don, Russian Federation. ${ }^{2}$ Professor, Department of Statistics, Econometrics and Risk Assessment, Rostov State University of Economics, Rostov-on-Don, Russian Federation.

${ }^{3}$ Associate Professor, Department of Statistics, econometrics and risk assessment, Rostov State University of Economics, Rostov-on-Don, Russian Federation.

${ }^{4}$ Associate Professor, Department of Statistics, econometrics and risk assessment, Rostov State University of Economics, Rostov-on-Don, Alexandra_a_t@mail.ru
} 


\section{Introduction}

The modern credit market in Russia began to take shape at the end of the 80s. Economic growth, started in the early 2000s, contributed to a marked increase in consumer lending. The financial crisis of 2008 slowed down the growth rates of lending, but in 2010 the lending volumes began to grow rapidly again. At the beginning of 2013 (CBR, 2019), loans granted to individuals reached $15.6 \%$ of the total assets of the Russian banking sector, $12.4 \%$ of GDP and $19.8 \%$ of population cash incomes.

The sharp jump in exchange rates, falling oil prices and Western sanctions in 2014 led to a reduction in real incomes of the population, a fall in the growth rate of consumer lending and a sharp increase in the level of overdue loans (Figure 1). In general, over four years, the fall in real disposable money incomes of the Russian population amounted to $11 \%$ of the level of 2013 (GKS RDCI, 2019). In 2018, the real disposable income of Russians decreased by $0.2 \%$ compared to the previous year, considering the one-time cash payment to pensioners in January 2017 (GKS SL, 2019). At the same time, starting from 2016, the volume of loans granted to the population began to grow sharply - by an average of 20-25\% annually (Figure 1).

Figure 1. Loans, total debt and overdue debt on loans granted to resident individuals, 2010-2019 (CBR, 2019)

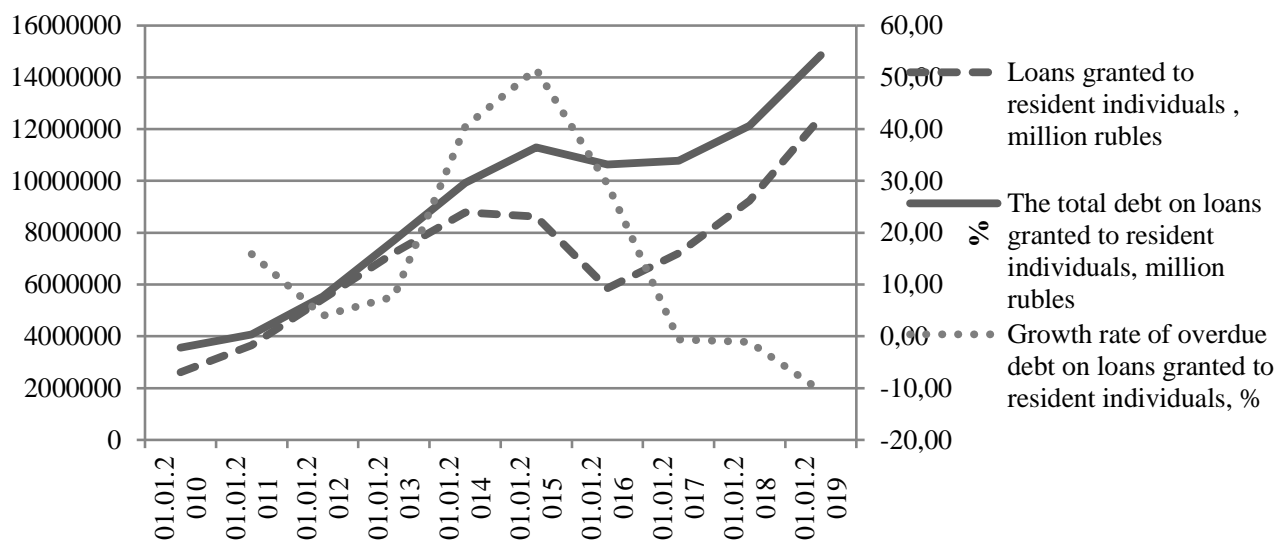

In such conditions, a further increase in the Russians credit activity, unsecured by a steady growth in real incomes, can create risks of insolvency of the population and an increase in the share of overdue debt in banks' loan portfolios. This in turn may have negative consequences for the banking sector. The current situation actualizes the need to analyze the behavior of households in the credit market. It should be noted that macroeconomic and banking statistics provide only a general picture of credit debt. While significant scientific and practical interest is the relationship between the household structure, the characteristics of its welfare and financial strategies in the credit market. 


\section{Theoretical, Empirical, and Methodological Grounds}

A noticeable surge of publications on the problems of population credit behavior occurred during the global economic crisis of 2008, since the economic downturn significantly affected both saving and credit behavior of the population. More than one study of domestic authors is devoted to studying the impact of the 2008 crisis. An analysis of their work may reveal some patterns of further developments of the current crisis (Thalassinos and Thalassinos, 2018; Rupeika-Apoga et al., 2018).

The rapid economic recovery after the 2008 crisis led to an unprecedented growth in lending from 2010, the prerequisites of which was examined by Gribova and Ibragimova (2011). They attempted to find out the basic attitudes of people towards loans and savings, as well as how they differ depending on their belonging to a sociodemographic group. Another study by Dimova and Efimova (2013) found a direct relationship between income and the value of loan debts, which was most evident among the wealthiest households, since they are the consumers of the most expensive loans, such as mortgage and car loans.

One of the negative consequences of the 2008 crisis was the growing insolvency of borrowers on loans. The reason for this was the "aggressive" credit behavior of the population in the pre-crisis period, which led to the fact that some borrowers became insolvent (Burdyak, 2012). Subsequently, banks were forced to raise interest rates on loans, which also served as an obstacle to new loans. Extensive analytical material detailing the impact of the crisis on the life of households and on their credit behavior, is also presented in the report of the authors of the Independent Institute for Social Policy (Maleva et al., 2011).

Analysis of the financial behavior of Russian households on the base of the Russian Longitudinal Monitoring Survey (RLMS-HSE) allowed identifying four main models of household behavior, depending on whether they save or borrow money (Tapilina and Bogomolova, 1998). Wealthy people account for the largest amounts of both savings and debt; however, there are many low-income families among savers. In the works of D.O. Strebkov a significant analytical material on the problems of lending to the population in the early 2000 s presented. According to the results of his analysis Strebkov (2004), proposed the practice of "living on credit" perceived by the population as a new, but very promising issue, and many respondents rated the loan not only inevitable, but also highly desirable for themselves and their families, to solve current financial problems.

In the works of Nivorozhkina (2016) problems of the impact of credit burden on household consumption in general were considered. According to the results of her analysis Nivorozhkina (2015) confirmed the negative impact of the growth in the credit burden on household spending on the educational needs of children. The most prone to applying for loans are complex families where several generations of 
relatives with children live together (Nivorozhkina et al., 2015). They normally have a high level of education, above average income, all employable members some of them are active and they primarily live in medium-sized cities of outsider regions. An important result of the recent analysis (Nivorozhkina et al., 2018) is evidence that hidden income is especially common among households that pay credits in the period of escalation of the social and economic crisis.

The growing interest of foreign researchers in the problems of household credit activity is also largely associated with the consequences of the 2008 global financial crisis. Empirical studies in the United States have revealed that a high level of the ratio of loans to household assets has a negative impact on household consumption expenditure (Dynan, 2012; Mian et al., 2013). Similar results are presented for several European countries (Benito et al., 2014; Andersen et al., 2014). The impact of credit debt on consumption elasticity can be done in two ways: either as a result of households not exceeding some fixed level of the ratio of loans to assets, or if financial institutions place limits on lending to highly indebted households.

Analysis of the credit activity of individuals (households) involves a comprehensive analysis of the factors that determine their behavior on credit market. For example, men more often than women apply for car loans, but apart from gender, his individual income, per capita household income, age, education, family composition and many other factors also affect the man's intentions. Important in such analysis is the assessment of the "pure" influence of each factor, the so-called "other things being equal" effect. We are interested in differences in the characteristics that determine the socio-demographic, professional profile of people (households) who pay loans, and those who do not have loans. The logistic model is an adequate econometric tool for solving this problem. Logistic regression makes it possible to predict the presence or absence of the studied characteristic (in our case, whether there are credit payments in the household or not) depending on a set of factors influencing the choice of behavior model.

Note that restricting the analysis to household credit behavior, in our view, narrows down the analysis. Even if the household unanimously decided to take out a loan, it is important that the household has an individual with the necessary set of characteristics for obtaining a loan, including income, since the credit organization enters into an agreement with an individual person and not a household. In this regard, it is important to conduct a comprehensive study of the relationship of household credit behavior both with its characteristics and with the characteristics of individuals, who greatly affect the choice of the household.

The credit activity of households can be assessed on the base of the Russian Longitudinal Monitoring Survey (RLMS-HSE), in which there are two types of surveys in each wave: household surveys and individuals. The survey of individuals includes answers to the questions "Are you going to take out a loan in the next 12 months?" and "For what purposes are you going to take out a loan?". 
When specifying the logistic model, it should be considered that surveys on households include questions about credit borrowings, their types, amounts paid, amounts of debt, while in individual surveys there are only questions about credit intentions. To analyze the structural and dynamic characteristics of the credit activity of the population, household files and files of individuals who answered the household questionnaire were combined.

Thus, to take into account all possible circumstances that determine the availability of credit in the household, for each year of the RLMS survey, we have formed databases of individuals, supplemented by the socio-demographic characteristics of the households in which they live, as well as their credit histories. Data was generated for 2006, 2008, 2012 and 2014. In our opinion, 2006 is the beginning of the mass entry into consumer and mortgage lending; 2008 - gave a signal that the deterioration of foreign economic background may lead to difficulties with loan repayments; 2012 is the peak of loan borrowing; and in 2014, signals of an approaching crisis appeared.

The data sets that are used have several limitations due to the subject of the study. The first one is age. The minimum age of an individual is 18 years. This is explained by the fact that 18 years is the age when a person begins to be considered as adult, and therefore, may submit documents on employment and official income confirmation to a credit institution. Some banks set a higher limit of age 23 years, since a young person may, for example, leave to serve in the army. Credit organizations limit the maximum age of the borrower: at the time of repayment of consumer credit, the female borrower should be no older than 55 years old; the man should not be older than 60 years old. In some banks, both levels have now been raised for 5 years each. It should be noted that age certainly affects the decision of the bank to issue a loan, even if the borrower age is within the limits set by the bank. Traditionally, banks give loans to young people reluctantly, especially when it comes to a large amount of credit. Banks prefer borrowers at the age of 25-40 years old, it is believed that they are the most solvent.

The next stage of the analysis is the definition of the general profile of the loan borrower, which includes the characteristics of individuals interviewed within the household. For this, we estimated binary Logit model, in which the dependent variable was the answer to the question: "Did your family spend money on loan repayment during the last 30 days?", which took a value equal to one in the case of "yes" answer and a value of zero for a negative response. This variable allows considering situations when the household paid, for example, a mortgage loan for many years, or a shortterm loan taken at the time closest to the time of the survey. That is, all households burdened with loans and borrowings at the time of the survey are considered.

The determinants were individual characteristics: gender, age, education level, type of employment, and household characteristics: settlement type, socio-demographic type of household, number of household members, and household income level (20\% income groups). 
For a significant part of households, the amount of cash expenditures and savings exceeded their disposable resources. That is, in the month when the survey was conducted, consumption was smoothed because the household either used borrowed funds or had some sources of informal income that were not indicated in the survey. To take this into account, another independent variable was used $(=1$, if the difference between disposable household resources and the amount of cash expenditures and savings turned out to be negative, and 0 otherwise.)

\section{Results}

Table 1 provides summary statistics of the variables to be used in further analysis. The first number in each of the cells in Table 1 is the percentage of responses of households paying loans, and the number in parentheses is the percentage of responses of households that do not repay loans. The sum of the percentages may be less than a $100 \%$, since there are several missing answers.

Table 1. Descriptive statistics used in the analysis of credit activity, \% of responses

\begin{tabular}{|c|c|c|c|c|}
\hline \multirow{2}{*}{ Variable } & \multicolumn{4}{|l|}{ Year } \\
\hline & 2006 & 2008 & 2012 & 2014 \\
\hline \multicolumn{5}{|c|}{ Quintiles of distribution of households' disposable per capita income } \\
\hline I & $16.86(20.92)$ & $14.58(22.11)$ & $18.21(25.80)$ & $20.17(20.92)$ \\
\hline II & $15.14(21.70)$ & $16.23(21.03)$ & $18.22(19.85)$ & $19.13(21.15)$ \\
\hline III & $17.20(19.86)$ & $20.29(20.35)$ & $18.52(17.30)$ & $18.02(21.08)$ \\
\hline IV & $25.92(18.52)$ & $22.37(18.52)$ & $20.73(17.85)$ & $18.48(20.03)$ \\
\hline $\mathrm{V}$ & $24.89(19.00)$ & $26.54(17.98)$ & $23.62(19.19)$ & $23.20(16.82)$ \\
\hline \multicolumn{5}{|l|}{ Gender of individual } \\
\hline Male & $44.95(45.32)$ & $41.89(45.94)$ & $46.01(46.76)$ & $44.95(47.57)$ \\
\hline \multicolumn{5}{|l|}{ Age group of individual } \\
\hline Up to 30 years & $27.06(27.48)$ & $24.67(27.46)$ & $29.22(26.50)$ & $20.38(23.64)$ \\
\hline From 30 to 40 years & $18.69(20.61)$ & $19.63(21.57)$ & $25.04(20.42)$ & $23.98(22.69)$ \\
\hline From 40 to 50 years & $24.89(24.54)$ & $25.77(23.01)$ & $21.05(20.62)$ & $24.57(22.72)$ \\
\hline Over 50 years & $26.38(24.40)$ & $26.75(25.23)$ & $22.44(30.38)$ & $28.44(28.66)$ \\
\hline \multicolumn{5}{|c|}{ Employment status of individual } \\
\hline Working & $67.89(64.73)$ & $68.98(68.88)$ & $73.73(61.99)$ & $65.27(66.89)$ \\
\hline On vacation & $1.61(2.19)$ & $2.41(2.12)$ & $3.78(2.38)$ & $2.56(2.59)$ \\
\hline Does not work & $30.50(33.01)$ & $29.61(30.01)$ & $22.36(35.52)$ & $32.18(30.49)$ \\
\hline \multicolumn{5}{|c|}{ Education level of individual } \\
\hline Incomplete secondary & $0.11(0.07)$ & $12.72(13.60)$ & $18.37(16.71)$ & $12.41(12.56)$ \\
\hline Completed secondary & $13.07(16.78)$ & $38.49(38.19)$ & $31.82(34.16)$ & $39.99(38.52)$ \\
\hline Completed vocational & $41.17(41.22)$ & $31.58(27.70)$ & $24.80(22.87)$ & $22.54(24.00)$ \\
\hline Completed higher education & $24.54(23.86)$ & $17.21(20.42)$ & $24.57(25.60)$ & $25.49(24.92)$ \\
\hline \multicolumn{5}{|l|}{ Settlement type } \\
\hline Regional center & $38.76(43.57)$ & $33.66(34.64)$ & $40.65(42.8)$ & $38.86(42.16)$ \\
\hline City & $32.45(25.70)$ & $28.07(28.00)$ & $26.75(24.39)$ & $31.72(28.30)$ \\
\hline Urban-type settlement & $5.62(5.81)$ & $8.11(7.82)$ & $5.96(6.42)$ & $4.33(6.66)$ \\
\hline Rural-type settlement & $23.17(24.91)$ & $30.15(29.54)$ & $26.64(26.38)$ & $25.10(22.89)$ \\
\hline \multicolumn{5}{|c|}{ Demographic type of household } \\
\hline Singles & $5.28(23.65)$ & $5.04(25.4)$ & $2.10(6.96)$ & $6.88(26.00)$ \\
\hline Household without children & $35.09(41.73)$ & $35.09(41.82)$ & $39.60(49.60)$ & $34.47(43.61)$ \\
\hline
\end{tabular}




\begin{tabular}{|l|l|l|l|l|}
\hline Household with children & $45.99(24.44)$ & $48.79(23.30)$ & $47.77(33.65)$ & $48.23(22.98)$ \\
\hline $\begin{array}{l}\text { Single-parent families and } \\
\text { other types of households }\end{array}$ & $13.65(10.18)$ & $11.07(9.48)$ & $10.54(9.79)$ & $10.42(7.41)$ \\
\hline $\begin{array}{l}\text { Cash expenditures and } \\
\text { savings > Disposable } \\
\text { resources }\end{array}$ & $54.93(40.67)$ & $53.07(39.84)$ & $51.60(37.00)$ & $47.71(30.49)$ \\
\hline
\end{tabular}

Note: Numbers in parentheses - percentages of responses of households without credits.

From 2006 to 2012, the share of borrowers of loans among relatively low-income groups increased. There may be several reasons for this. The first one is that from 2006 to 2014, real incomes of the population increased and, respectively, loans for poor households became more affordable. The second one is that during this period, banks reduced their loan requirements; besides the number of microfinance organizations increased dramatically, in order to get a loan in which a passport is enough to get a loan. Often borrowers, due to their low financial literacy, were not fully aware of the size of payments for such loans, and as a result the poorest households had to make extremely high loan payments.

Individual characteristics of respondents representing households indicated that borrowers are more often working women, the age of borrowers shifted over to the older age groups. We can see that more often loans were taken by people with incomplete secondary and secondary general education, which can be explained by the massive advertising of various loans, their increased availability and lack of financial literacy of the population, which led to an increase in overdue loans. The share of single people among borrowers is much less than among those who do not take loans. Among households with children, the share of borrowers is almost twice the proportion of those who do not have loans. A serious signal is the fact that among borrowers the share of those whose expenses exceed their incomes is higher than among those who have no loans. For further analysis we estimated binary Logit model, the estimation results in terms of the odds ratio are shown in Table 2.

Table 2. The binary Logit model of credit activity of households and their members, odds ratio, 2006, 2008, 2012, 2014

\begin{tabular}{|l|l|l|l|l|}
\hline \multirow{2}{*}{ Variable } & Year & \multicolumn{4}{l|}{} \\
\cline { 2 - 5 } & 2006 & 2008 & 2012 & 2014 \\
\hline Quintiles of distribution of households' disposable per capita income (III) \\
\hline I & $0.602^{* * *}$ & $0.475^{* * *}$ & $0.456^{* * *}$ & $0.602^{* * *}$ \\
\hline II & $0.780^{*}$ & 0.825 & $0.787^{* * *}$ & 0.847 \\
\hline IV & $1.784^{* * *}$ & $1.326^{* *}$ & $1.211^{* *}$ & 1.157 \\
\hline V & $1.870^{* * *}$ & $1.878^{* * *}$ & $1.490^{* * *}$ & $2.160^{* * *}$ \\
\hline Gender of individual (female & \multicolumn{5}{|l}{} \\
\hline Male & 0.985 & $0.843^{* *}$ & $0.919^{* *}$ & 0.905 \\
\hline Age group of individual (from 30 to 40 years) & \multicolumn{1}{l|}{} \\
\hline Up to 30 years & 1.130 & 0.960 & $1.149^{* *}$ & $0.778^{* *}$ \\
\hline From 40 to 50 years & 1.116 & $1.256^{*}$ & 0.976 & 0.974 \\
\hline Over 50 years & $1.225^{*}$ & 1.143 & 0.913 & 0.895 \\
\hline Employment status of individual (working) \\
\hline
\end{tabular}




\begin{tabular}{|c|c|c|c|c|}
\hline On vacation & 0.648 & 1.317 & 1.082 & 1.119 \\
\hline Does not work & 0.945 & 0.928 & $0.592 * * *$ & $1.144^{*}$ \\
\hline \multicolumn{5}{|c|}{ Education level of individual (completed vocational) } \\
\hline Incomplete secondary & $0.727 * *$ & 0.858 & $1.161 * *$ & 1.153 \\
\hline Completed secondary & 0.966 & 0.883 & 0.982 & 1.118 \\
\hline Completed higher education & 1.110 & $0.776 * *$ & $0.741 * * *$ & 1.096 \\
\hline \multicolumn{5}{|c|}{ Settlement type (regional center) } \\
\hline City & $1.698 * * *$ & 1.021 & $1.258 * * *$ & $1.348^{* * *}$ \\
\hline Urban-type settlement & 1.292 & 1.058 & 1.120 & $0.691 * *$ \\
\hline Rural-type settlement & $1.381 * *$ & 0.972 & $1.345 * * *$ & $1.438^{* * *}$ \\
\hline \multicolumn{5}{|c|}{ Demographic type of household (household without children) } \\
\hline Singles & $0.304 * * *$ & $0.236 * * *$ & $0.340 * * *$ & $0.324 * * *$ \\
\hline Household with children & $2.198 * * *$ & $2.181 * * *$ & $1.623 * * *$ & $2.668^{* * *}$ \\
\hline $\begin{array}{l}\text { Single-parent families and } \\
\text { other types of households }\end{array}$ & $1.801 * * *$ & $1.345^{*}$ & $1.340 * * *$ & $1.919 * * *$ \\
\hline $\begin{array}{lll}\text { Number } \\
\text { members }\end{array}$ of household & $1.118 * *$ & - & 1.027 & $1.070^{*}$ \\
\hline $\begin{array}{l}\text { Cash expenditures and } \\
\text { savings }>\text { Disposable } \\
\text { resources }\end{array}$ & $2.214 * * *$ & $2.102 * * *$ & $2.332 * * *$ & $2.551^{* * *}$ \\
\hline Children under 3 years old & 1.264 & 1.279 & 1.026 & 1.151 \\
\hline Children from 3 to 7 years & 1.043 & 1.119 & $1.221 * * *$ & 1.068 \\
\hline Children from 7 to 18 years & 0.854 & 1.066 & 1.022 & 0.959 \\
\hline Constant & $0.083 * * *$ & $0.184 * * *$ & $0.328 * * *$ & $0.183^{* * * *}$ \\
\hline Pseudo $\mathrm{R}^{2}$ & 0.113 & 0.124 & 0.075 & 0.127 \\
\hline Sample size & 3798 & 3690 & 10701 & 4576 \\
\hline
\end{tabular}

Note: $* * *, * *, *$ is significant at the level of 1,5 , and $10 \%$, respectively.

The reference categories are shown in parentheses.

We found that men are less likely than women to be those who have a loan in the household, and this trend is stable. There is a slight decrease in this ratio in 2008 and 2014 crisis periods. The impact of education level on household credit behavior is not clear - different levels of education have been statistically significant in different years. In 2006, individuals with incomplete secondary education are less likely to have a loan compared to those with completed vocational education; in 2008 and 2012, individuals with higher education are significantly less likely to have a loan. The effect of employment status on household credit behavior is statistically significant in 2012 - the chances of having a loan among unemployed were half lower as among those employed. Compared to individuals aged 30 to 40 , all others had a higher chance to have a loan, and in 2014 - lower. Individuals living in regional centers are the least active borrowers.

The more members in the household, the more often these families apply for loans. Compared to households without children, single people apply for loans much less frequently, and households with children - more often. At the same time, households with children under 7 years old have loans most often. Per capita family income has a statistically significant effect on their credit activity - households from higher income groups are more likely to take loans, and poorer ones are less likely, compared 
with the third income group. It should be noted that, households, where disposable resources were lower than cash expenses and savings in the month of the survey, took loans much more often: the odds ratio in all studied periods was more than two.

\section{Conclusions and Recommendations}

The results of the study allow us to formulate the following conclusions. Loan borrowings are more often found in households with children of preschool age who are in relatively high-income groups, who much more often inform about cash incomes that do not correspond to the declared level of consumption. Members of these households are more likely to work. The age range of borrowers expanded during the study period, and no prevalence of any age group was observed.

We found that the hypothesis that individual characteristics are important determinants of household lending activity has not been confirmed. And variables that characterize households significantly affect their credit behavior. This result is of great practical importance, since, as already indicated, in assessing the solvency of the borrower, credit organizations are mainly focused on individual characteristics.

\section{References:}

Andersen, A.L., Duus, C., Jensen, T.L. 2014. Household debt and consumption during the financial crisis: evidence from Danish micro data. Danmarks National Bank Working Paper, 89.

Benito, A., Waldron, M., Young G., Zampolli, F. 2007. The role of household debt and balance sheets in the monetary transmission mechanism. Bank of England Quarterly Bulletin, 47(1), 70-89.

Burdyak, A.Ya. 2012. Credit behavior of households and an economic crisis. XII International Academic Conference on Economic and Social Development: Conference proceedings, vol. 3, 431-439.

CBR. 2019. Statistics on loans in Russia. Available at: http://www.cbr.ru/statistics/UDStat.aspx?Month=01\&Year=2019\&TblID=302-02M

CBR. 2019. Review of the banking sector of the Russian Federation, Central Bank of Russia. Available at: http://www.cbr.ru/analytics/bank_system/obs_1303.pdf

Dimova, N.A., Efimova, I.A. 2013. Credit behavior of population. Bulletin of the Russian Longitudinal Monitoring Survey (RLMS-HSE), 165-186.

Dynan, K. 2012. Is a household debt overhang holding back consumption? Brookings Papers on Economic Activity, Economic Studies Program, The Brookings Institution, 44(1), 299-362.

GKS RDCI. 2019. Data on real disposable cash income in Russia Available at: http://www.gks.ru/free doc/new_site/population/urov/urov_12kv.doc

GKS SL. 2019. Data on standard of living in Russia. Available at: http://www.gks.ru/bgd/free/B18 00/IssWWW.exe/Stg/dk12/6-0.doc

Gribova, E.A., Ibragimova, D.Kh. 2011. Population's attitudes towards savings and loans. Bulletin of the Russian Longitudinal Monitoring Survey (RLMS-HSE), 121-130.

Maleva, T.M., Zubarevich, N.V., Ovcharova, L.N. 2011. The impact of the 2008-2009 crisis on changes in the economic situation, savings and credit behavior of the population in 
Russia. The economic situation of the population, Sberbank of Russia, available at: http://www.sbrf.ru/common/img/uploaded/files/pdf/press_center/2011/03/nisp_11022 8.pdf.

Mian, A.R., Rao, K., Sufi, A. 2013. Household balance sheets, consumption, and the economic slump. The Quarterly Journal of Economics, 128(4), 1687-1726.

Nivorozhkina, L.I. 2016. Impact of consumer crediting on household consumption: economic and statistical study. Voprosy statistiki, 1, 47-54.

Nivorozhkina, L.I. 2015. Impact of consumer lending on conditions of forming human capital assets in disadvantaged children. Accounting and Statistics, 1(37), 88-95.

Nivorozhkina, L.I., Toropova, T.V., Yarashanova, E.U., Batashev, R.V. 2015. Modeling of financial behavior of the population. Mediterranean Journal of Social Sciences, 6, MCSER Publishing, 337-348.

Nivorozhkina, L.I., Tregubova, A.A., Batashev, R.V. 2018. Influence of households' borrowings on consumer spending during the escalation of the crisis. European Research Studies Journal, 21, Special Issue 2, 485-496.

RLMS-HSE. 2019. Russian Longitudinal Monitoring Survey. Available at: https://www.hse.ru/en/rlms/

Rupeika-Apoga, R., Zaidi, H.S., Thalassinos, E.Y. and Thalassinos, I.E. 2018. Bank Stability: The Case of Nordic and Non-Nordic Banks in Latvia. International Journal of Economics and Business Administration, 6(2), 39-55.

Strebkov, D.O. 2004. The main types and factors of credit behavior of the population in modern Russia. Voprosy Ekonomiki, 2, 109-128.

Tapilina, V.S., Bogomolova, T.Yu. 1998. Who spends on what. Financial behavior of Russian households. ECO journal, 10, 119-128.

Thalassinos, I.E., Thalassinos, Y. 2018. Financial Crises and e-Commerce: How Are They Related. Available at SSRN: https://ssrn.com/abstract=3330169. 